\title{
KLAUZULA DOBRA DZIECKA W KONWENCJI O PRAWACH DZIECKA I W PRAWIE POLSKIM (WYBRANE PROBLEMY)
}

\begin{abstract}
Streszczenie. Prawa dziecka należą do najistotniejszych i najbardziej wymagających regulacji zarówno na arenie międzynarodowej, jak i w ustawodawstwie krajowym. Zarówno w Konwencji o prawach dziecka, jak i w prawie polskim wyrażony został nakaz kierowania się dobrem dziecka. Klauzula dobra dziecka wypełniana jest treścią przez doktrynę oraz judykaturę. Dobro dziecka stanowi wartość nadrzędną, inne dobra i interesy nie powinny mieć pierwszeństwa przed tą zasadą. W przypadku kolizji interesów dobro dziecka powinno mieć znaczenie priorytetowe. Artykuł ten ma na celu przedstawienie kondycji praw dziecka w Polsce, ze szczególnym uwzględnieniem klauzuli dobra dziecka w świetle Konwencji o prawach dziecka i polskich przepisów.
\end{abstract}

Slowa kluczowe: dziecko, prawa dziecka, dobro dziecka, klauzula dobra dziecka, Konwencja o prawach dziecka.

\section{WSTĘP}

Prawa człowieka, ze swoją szczególną specyfiką uwarunkowaną charakterem stosunków społecznych, należały niegdyś do wyłącznej kompetencji poszczególnych państw. Współcześnie, dzięki inicjatywom na rzecz praw człowieka, problematyka ta uregulowana została zarówno w umowach międzynarodowych, jak i wdrożona przez prawodawców krajowych.

Idea praw człowieka rozkwitła w pełni dopiero w XX w., a stopniowo wraz z nimi uformowała się koncepcja praw dziecka. Społeczność międzynarodowa podjęła inicjatywę uznania podstawowych praw dziecka w latach 20. ubiegłego stulecia dzięki staraniom Międzynarodowego Związku Pomocy Dzieciom, przy czym najpełniejszą realizację zadań na rzecz dzieci przypisać należy działaczce Englantyne Jebb (Łopatka 2000, 10). Jeszcze w 1924 r. uchwalono genewską Deklarację Praw Dziecka, a równocześnie z nią powołano Fundusz Narodów Zjednoczonych na Rrzecz Dzieci - UNICEF. Do deklaracji genewskiej nawiązywała również uchwalona 20 listopada 1959 r. przez Zgromadzenie Ogólne Narodów Zjednoczonych (ONZ) Deklaracja Praw Dziecka (DPD). Nie ulega jednak wattpliwości, że dopiero uchwalona w 30. rocznicę DPD, Konwencja o prawach dziecka

* Uniwersytet Łódzki, Wydział Prawa i Administracji, Katedra Teorii i Filozofii Prawa, mendecka.k@gmail.com 
(KPD, Konwencja) (Dz. U. 1991, Nr 120, poz. 526) była pierwszym prawnie wiążącym dokumentem międzynarodowym na taką skalę ${ }^{1}$.

Obecnie międzynarodowy porządek prawny dotyczący praw dziecka w znacznej mierze oparty jest na standardach wyznaczonych przez ONZ, Radę Europy i Unię Europejską (UE). Ze względu na ramy niniejszej publikacji omawiana będzie wyłącznie inicjatywa ONZ na rzecz ochrony dzieci, wyrażona w Konwencji o prawach dziecka.

Konwencja o prawach dziecka jest wielostronna, uniwersalną umową międzynarodową dotycząca praw człowieka i podstawowych wolności. Co interesujące, Polska miała znaczący udział w tworzeniu Konwencji - składając propozycje tekstu Konwencji i będąc w pierwszej grupie państw, które ją podpisały (Kuźniar 1992, 80).

Włączenie Konwencji do polskiego systemu gwarantuje obecnie art. 91 ust. 1 Konstytucji RP z dnia 2 kwietnia 1997 r. (Dz. U. 1997, Nr 78, poz. 483). Oznacza to, że powinna być bezpośrednio stosowana, gdyż z momentem ratyfikacji stała się częścią krajowego porządku prawnego.

W związku z upływem ponad dwóch dekad od wejścia w życie KPD konieczne staje się nowe spojrzenie na kondycję przestrzegania praw dziecka w Polsce, ich usankcjonowanie przez prawodawce, a także stosowanie przez judykaturę zawartych w Konwencji zaleceń. Jedną z najtrudniejszych, a zarazem najważniejszych dyrektyw wyznaczonych przez Konwencję jest nakaz kierowania się dobrem dziecka wyrażony w art. 3 Konwencji. Należy zatem wyjaśnić znaczenie tego pojęcia i doniosłość jego interpretacji zarówno w świetle samej Konwencji, jak i na płaszczyźnie krajowej.

Artykuł ten ma na celu krótką analizę wybranych problemów pojęciowych i interpretacyjnych klauzuli dobra dziecka w świetle brzmienia i celów Konwencji o prawach dziecka oraz przepisów polskich. Przedstawione zostaną również uwagi Komitetu Praw Dziecka dotyczące interpretacji dobra dziecka w Polsce. Zostanie podjęta próba omówienia zależności pomiędzy interesem dziecka a interesami innych osób oraz interesu społecznego. Problem ten pozostaje wciąż aktualny w bieżącym dyskursie prawnopolitycznym i dlatego teoretyczna oraz praktyczna analiza wydaje się potrzebna.

\section{ROZWÓJ POJĘCIA „DOBRO DZIECKA”}

Pojęcie „dobro dziecka” po raz pierwszy zostało użyte w Deklaracji Praw Dziecka z 20 listopada 1959 r. (zasada 2) ${ }^{2}$ oraz w Konwencji w sprawie likwidacji wszelkich form dyskryminacji kobiet z 18 grudnia 1979 r. w art. 5 i 16 (Dz. U. 1982, Nr 10,

${ }^{1}$ Kwestia praw dziecka poruszana jest również w wielu innych międzynarodowych aktach, takich jak Karta Praw Podstawowych, Międzynarodowy Pakt Praw Obywatelskich i Politycznych, jednakże ramy niniejszej publikacji nie pozwalają na szersze ich omówienie.

2 http://ms.gov.pl/Data/Files/_public/ppwd/akty_prawne/onz/deklaracja_praw_dziecka. pdf [dostęp 27.06.2016]. 
poz. 71). Należy przy tym zauważyć, że w powojennym, socjalistycznym ustawodawstwie polskim zwrot ten używany był już wcześniej, gdyż Dekret z dnia 22 stycznia 1946 r. (Dz. U. 1946, Nr 6, poz. 52) stanowił w art. 20 § 3, że ,obowiązkiem rodziców jest sprawować władzę rodzicielską tak, jak tego wymaga dobro dzieci i interes społeczeństwa”. Nakaz kierowania się dobrem dziecka był też wprowadzony w Konstytucji PRL z dnia 22 lipca 1952 r. (Dz. U. 1952, Nr 33, poz. 232). Również Kodeks rodzinny i opiekuńczy (KRO) z dnia 25 lutego 1964 r. (Dz. U. 1964, Nr 9, poz. 59) posługuje się pojęciem dobra dziecka. Obecnie odesłanie do dobra dziecka znajduje wsparcie norm konstytucyjnych zawartych w 4 punktach art. 72 Konstytucji RP.

Konwencja o prawach dziecka również posługuje się wielokrotnie pojęciem dobra dziecka. W angielskiej wersji Konwencji używa się wyłącznie zwrotu ,the best interest of the child", podobnie niemieckojęzyczna wersja tłumaczenia posługuje się jednym zwrotem na określenie dobra dziecka - „Kindeswohl”. Natomiast w polskiej wersji językowej zamiennie stosuje się pojęcia ,interes dziecka” (art. 3), „najlepiej pojęty interes dziecka” (art. 9 i 18), ,dobro” (art. 20), ,dobro dziecka” (art. 21), „najwyższe dobro dziecka” (art. 37), „najwyższy interes dziecka” (art. 40). Ta niespójność zdaje się nie znajdować uzasadnienia, ponieważ wprowadza chaos pojęciowy (Radwański 2009, 50-65). Pomimo terminologicznej rozbieżności, w polskiej judykaturze i literaturze ,interes” dziecka jest utożsamiany z ,dobrem” dziecka (Stojanowska 1994, 33-41) ${ }^{3}$.

\subsection{Definicja „dziecka” w Konwencji i prawie polskim}

W literaturze podnosi się, że dobro dziecka jest „duchem ustawy” zarówno Konwencji, jak i wszystkich przepisów kodeksu rodzinnego i innych ustaw dotyczących dzieci (Stojanowska 1999). Dziecko, w świetle art. 1 Konwencji, to każda osoba poniżej osiemnastu lat, chyba że zgodnie z prawem uzyska wcześniej pełnoletność. Takie kryterium wieku jest najczęściej występującym wyznacznikiem dorosłości. Również w rozumieniu ustawy z dnia 6 stycznia 2000 r. o Rzeczniku Praw Dziecka (RPD) (Dz. U. 2000, Nr 6, poz. 69) dziecko to każda istota ludzka do uzyskania pełnoletności (art. 2.1), a w przypadku kobiet dorosłość osiaga się również poprzez zawarcie małżeństwa w wieku 16 lat (art. $10 \mathrm{KRO}$ ).

Konwencja nie określa natomiast początkowej granicy, od której przyznaje się ochronę praw dziecka. Kompromis ten należy uznać za świadomy, gdyż ustawodawstwa państw różnie regulują dopuszczalność aborcji (Balcerzak, Sykuna 2010, 81). Polskie prawo przyjmuje moment poczęcia za kryterium początku życia (art. 2.1. ust. RPD), a aborcja jest dozwolona jedynie w trzech restrykcyjnie określonych przypadkach ${ }^{4}$.

\footnotetext{
${ }^{3}$ Zob. też postanowienie Sądu Najwyższego z dnia 5 lipca 2006 r. IV CSK 127/06.

${ }^{4}$ Zob. ustawa z dnia 7 stycznia 1993 r. o planowaniu rodziny, ochronie płodu ludzkiego i warunkach dopuszczalności przerywania ciąży, Dz. U. 1993, Nr 17, poz. 78.
} 


\section{3. „Dobro dziecka” w Konwencji o prawach dziecka}

Konwencja nie precyzuje, na czym polega dobro dziecka, brak też części ogólnej, która mogłaby zawierać normy interpretacyjne, takie jak wymóg kierowania się dobrem dziecka w każdej sprawie. Natomiast art. 3 KPD określa, że zarówno dla publicznych, jak i prywatnych instytucji opieki społecznej, sądów, władz administracyjnych i ciał ustawodawczych nadrzędną sprawą powinno być zawsze najlepsze zabezpieczenie interesów dziecka. Zdaje się zatem, zgodnie z poglądami części doktryny, że dobro dziecka, wyrażone w tym przepisie, powinno być instrumentem wykładni dla całej Konwencji, a artykuł ten należy zaliczyć do postanowień „ogólnych” (Stojanowska 1999; Radwański 1991). Interesujące myśli przewodnie znajdują się w preambule KPD, która podkreśla takie wartości, jak: wychowanie w środowisku rodzinnym (mające zapewnić harmonijny i pełny rozwój) oraz w tradycji i kulturze danego narodu (w którym dziecko przyszło na świat) jako wskazujące kierunek interpretacyjny pojęcia „dobro dziecka”. Dalsze artykuły Konwencji dodatkowo uzupełniają pojęcie „dobra dziecka”, i tak: art. 9 stanowi, że dobro dziecka jest nadrzędnym kryterium w stosunku do praw rodziców i innych osób. Jako dobro dziecka należy rozumieć np. możliwość wypowiadania się w postępowaniach sądowych dotyczących dziecka (art. 12), możliwość korzystania z zakładów opiekuńczych (art. 18), życia w środowisku rodzinnym (art. 20) oraz oczywiście zakaz tortur i poniżającego traktowania (art. 37).

W Uwagach ogólnych nr 14 (2013) Komitetu Praw Dziecka (Komitet) dotyczących klauzuli dobra dziecka - jako najważniejszej przesłanki we wszystkich działaniach dotyczących dzieci (tłum. - K.M.) $)^{5}$ przyjęto, że klauzula jest złożona i konieczne jest indywidualne ustalanie jej znaczenia przez podmioty zajmujące się sprawami dotyczącymi dzieci. Komitet zaleca, aby klauzula była za każdym razem definiowana na nowo w świetle konkretnych okoliczności i przepisów Konwencji. Komitet wyraził przy tym ocenę, iż pomimo swojej elastyczności, klauzula dobra dziecka bywa często nadużywana przez państwa-strony Konwencji, w tym Polskę.

\subsection{Prawo polskie w relacji do Konwencji o prawach dziecka}

Komitet Praw Dziecka jako organ kontrolujący implementację postanowień Konwencji o prawach dziecka posiada gwarancje proceduralne ograniczone do mechanizmu badania sprawozdań państw-stron i tzw. pilnej procedury (co polega na podaniu informacji) (Balcerzak, Sykuna 2010, 81). Polska zobowiązała się do sporządzania sprawozdań przygotowywanych przez Ministerstwo Edukacji

${ }^{5}$ Zob. General comment No. 14 (2013) on the right of the child to have his or her best interest taken as a primary consideration (art. 3, para. 1), CRC/C/GC/14, 29 May 2013, 10. 
Narodowej co pięć lat ${ }^{6}$. W odpowiedzi na nie Komitet przedstawia Uwagi końcowe do sprawozdań Polski.

W ostatnich Uwagach końcowych Komitet (do połączonego trzeciego i czwartego sprawozdania, $\mathrm{CRC} / \mathrm{C} / \mathrm{POL} / \mathrm{CO} / 3-4$ z 30 października) wyraził swoje zaniepokojenie co do sytuacji polskich dzieci i poszanowania ich praw oraz przestrzegania ich dobra w każdym wypadku. Przede wszystkim Komitet wskazał na tradycyjne postawy, które utrudniają poszanowanie zasady niedyskryminacji, utrzymują stereotypy dotyczące ról kobiet i mężczyzn, orientacji seksualnej oraz religii. Ponadto zwrócił uwagę na brak dostępu do edukacji seksualnej dostosowanej do wieku, zbyt restrykcyjne przepisy dotyczące przerywania ciąży u nieletnich (co prowadzi do niebezpiecznych i zagrażającym życiu nielegalnych aborcji). Komitet wezwał też Polskę do wycofania się z deklaracji interpretacyjnej, którą Polska zgłosiła do artykułów 12-16 oraz 24 Konwencji ${ }^{7}$. W odpowiedzi na to Polska wystosowała Stanowisko do uwag końcowych Komitetu Praw Dziecka, w którym odniosła się bezpośrednio do stawianych zarzutów i potwierdziła złożone uprzednio deklaracje: „w odniesieniu do art. 24 ust. 2f Konwencji Rzeczpospolita Polska uważa, że poradnictwo dla rodziców oraz wychowawców oraz wychowanie w zakresie planowania rodziny powinno pozostawać w zgodzie z zasadami moralności"”. Rząd polski ponadto stoi na stanowisku, że postanowienia Konwencji nie dają Komitetowi podstaw, by nakładać na Polskę obowiązek wprowadzenia do prawa krajowego regulacji dotyczących dostępu do poradnictwa lekarskiego bez zgody rodziców, dostępu do antykoncepcji bez zgody rodziców i dopuszczalności aborcji. Potwierdzono przy tym deklarację dotyczącą art. 12-16, że „wykonanie przez dziecko jego praw określonych w Konwencji [...] dokonuje się z poszanowaniem władzy rodzicielskiej, zgodnie z polskimi zwyczajami i tradycjami dotyczącymi miejsca dziecka w rodzinie i poza rodziną".

Niestety, ramy tej pracy nie pozwalają na szersze omówienie powyższych zagadnień, należy jednak o nich wspomnieć, szczególnie w aspekcie władzy rodzicielskiej a dobra dziecka. Wydaje się słuszna teza, że dobro dziecka, będące wartością nadrzędną, powinno faktycznie być preferowane, nawet w kontekście władzy rodzicielskiej. Poddać też należy rozważaniom, czy rzeczywiście

\footnotetext{
${ }^{6}$ Do tej pory wszystkie sprawozdania sporządzane były z opóźnieniem.

${ }^{7}$ Polska zgłosiła również zastrzeżenia do KPD, które wycofała 4 marca 2013, o treści: „W odniesieniu do art. 7 Konwencji: RP zastrzega, że prawo dziecka przysposobionego do poznania rodziców naturalnych będzie podlegało ograniczeniu poprzez obowiązywanie rozwiązań prawnych umożliwiających przysposabiającym zachowanie tajemnicy pochodzenia dziecka” oraz „O granicy wieku, od której dopuszczalne jest powoływanie do służby wojskowej lub podobnej oraz uczestnictwo w działaniach zbrojnych, rozstrzyga prawo RP. Granica ta nie może być niższa niż przewidziana w art. 38 KPD".

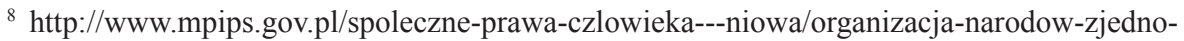
czonych---powszechny-system-ochrony-praw-czlowieka/konwencja-o-prawach-dziecka/wykonywanie-konwencji-o-prawach-dziecka-przez-polske/ [dostęp 26.06.2016].
} 
deklaracje złożone przez Polskę, szczególnie niejasne takie pojęcia, jak „,moralność”, „polskie zwyczaje i tradycje”, mogą w istocie pomijać najważniejszy postulat, jakim jest dobro dziecka.

\section{5. „Dobro dziecka” w ustawodawstwie polskim}

Podobnie jak w Konwencji o prawach dziecka, w polskim systemie prawnym nie występuje definicja ustawowa „,dobra dziecka”, chociaż judykatura i doktryna dazżą do konkretyzacji tego pojęcia. Ponadto w literaturze podnosi się, że polskie prawo przewiduje dalej idącą i pełniejszą ochronę dobra dziecka niż wynika to z Konwencji (Stojanowska 1994, 33-41).

Pojęcie dobra dziecka szczególnie często występuje w Kodeksie rodzinnym i opiekuńczym. Dobro małoletniego dziecka jest przesłanką negatywną przy przysposobieniu (art. $125 \mathrm{KRO}$ ), podobnie jak w przypadku rozwodu (art. $56 \S$ $6 \mathrm{KRO}$ ). Jak zauważa T. Smyczyński, „zasada dobra dziecka, jako istoty słabszej od innych i potrzebującej ochrony, przenika całe prawo rodzinne niezależnie od tego, w jakim akcie prawnym unormowano konkretny fragment stosunków rodzinnych" (Smyczyński 2012, 19). Podobny pogląd podziela W. Stojanowska, która ponadto podkreśla, że „dobro dziecka powinno być brane pod uwagę podczas stosowania każdego przepisu prawa mającego związek z sytuacją dziecka jako dobro nadrzędne. Aby tę powinność wyegzekwować, należy sprecyzować wyraźny nakaz tego rodzaju postępowania" (Stojanowska 1999).

Również w postanowieniu Sądu Najwyższego (SN) z dnia 5 lipca 2006 r. IV CSK 127/06 sąd przychylił się do tego stanowiska, „dobro (interes) dziecka ma znaczenie nadrzędne i wymaga rozważenia w każdej sprawie dotyczącej opieki nad małoletnim, a więc również w sprawie o jego przysposobienie i to zarówno krajowe, jak i zagraniczne [...] z przepisów konwencyjnych, zwłaszcza $\mathrm{z}$ art. 3 wynika, że wartością pierwotną i nadrzędną jest dobro dziecka. Treść tego pojęcia, ustalona wedle wskazań obowiązującego prawa polskiego, odpowiada w ogólnych zarysach pojęciu nadrzędnego interesu dziecka".

Dobro dziecka było też przedmiotem rozważań Trybunału Konstytucyjnego. Trybunał w wyroku z dnia 28 kwietnia 2003 r. K 18/02 podniósł, że „nakaz ochrony dobra dziecka stanowi podstawową, nadrzędną zasadę polskiego systemu prawa rodzinnego, której podporządkowane są wszelkie regulacje w sferze stosunków pomiędzy rodzicami i dziećmi [...]”. Trybunał przyjął też, że „pojęcie praw dziecka w przepisach Konstytucji należy rozumieć jako nakaz zapewnienia ochrony interesów małoletniego, który w praktyce sam może jej dochodzić w bardzo ograniczonym zakresie. Dobro dziecka jest również tą wartością która determinuje kształt innych rozwiązań instytucjonalnych, w tym przede wszystkim na gruncie Kodeksu rodzinnego i opiekuńczego".

W doktrynie znacznie precyzyjniej definiuje się dobro dziecka. W. Stojanowska zaproponowała, żeby pojęcie to rozumieć jako „kompleks wartości 
o charakterze niematerialnym i materialnym niezbędnych do zapewnienia prawidłowego rozwoju fizycznego i duchowego dziecka oraz do należytego przygotowania go do pracy odpowiednio do jego uzdolnień, przy czym wartości te są zdeterminowane przez wiele różnorodnych czynników, których struktura zależy od treści stosowanej normy prawnej i konkretnej, aktualnie istniejącej sytuacji dziecka, zakładając zbieżność tak pojętego dobra dziecka z interesem społecznym" (Stojanowska 1979, 27). Inną definicją, zaproponowaną przez S. Kołodziejskiego, jest rozumienie dobra dziecka jako „zespołu wartości, zarówno duchowych, jak i materialnych, jakie konieczne są do prawidłowego: a) rozwoju fizycznego dziecka, b) rozwoju duchowego dziecka, c) należytego przygotowania go do pracy dla dobra społeczeństwa" (Kołodziejski 1965, 30).

Odwołując się do powyższych definicji w literaturze i judykaturze, pomimo różnic w wykładni, można zauważyć, że dobro dziecka jest interpretowane przede wszystkim jako mające charakter nadrzędny i stanowi rdzeń wszystkich przepisów o prawach dziecka.

\section{KLAUZULE GENERALNE}

Jak zostało wyżej wyjaśnione, pojęcie dobra dziecka nie posiada powszechnie przyjętej definicji na płaszczyźnie normatywnej ani doktrynalnej, pomimo że zwrot ten używany jest powszechnie zarówno w dokumentach międzynarodowych (Konwencja o prawach dziecka), jak i w ustawodawstwie polskim. Jest to zwrot niedookreślony, co jest charakterystyczne dla klauzul generalnych, do których klauzula dobra dziecka jest zaliczana.

Chociaż w piśmiennictwie istnieją rozbieżności co do zakresu samego pojęcia klauzula generalna, to część autorów podobnie definiuje funkcje klauzul generalnych jako ,środek dostosowania prawa ustawowego do konkretnych sytuacji życiowych, za pomocą udzielonej organowi stosującemu prawo kompetencji do posługiwania się w pewnych przypadkach ocenami i regułami pozaprawnymi” (Piszko 2001, 22, za: Wróblewski 1964, 12). Podobnie część doktryny utożsamia terminy „klauzula generalna” i „odesłanie”, chociaż nie jest to pogląd powszechnie przyjęty (Nowacki 2003). Pomimo tych rozbieżności w doktrynie, z uwagi na zakres tego artykułu, można skłonić się ku definicji, że klauzule generalne to zazwyczaj dwu- lub trzywyrazowe zwroty, gdzie pierwszy człon odsyła do dyrektyw mających uzasadnienie aksjologiczne, a więc abstrakcyjnych zjawisk czy wartości (tu: dobro), a drugi wskazuje kryterium pozaprawne, służące za treściową podstawę wypowiadania ocen (tu: dziecko) (Leszczyński 1986, 19). Pomimo tego, że klauzule odsyłają do kategorii pozaprawnych, są zwrotem języka aktu prawnego. Można zgodzić się z L. Leszczyńskim, że ,przez klauzulę prawną należy rozumieć zwrot nieokreślony znaczeniowo, będący częścią przepisu prawnego, odsyłający do ogólnie 
ukierunkowanych, ocennych kryteriów pozaprawnych, którego konkretna treść ustalana jest w procesie stosowania prawa" (tamże)

W konsekwencji nie budzi wątpliwości konkluzja, że prawodawca sformułował klauzule generalne nieprzypadkowo i świadomie, uznając je za właściwy sposób normatywnej regulacji. W literaturze przyjmuje się, że forma klauzuli nie jest przypadkowa, dlatego brak definicji „,dobra dziecka” należy uznać za zabieg celowy (tamże, 77). Niewątpliwie, zamknięcie tego zwrotu w ścisłe ramy definicji ustawowej byłoby niepożądane, ponieważ ograniczyłoby możliwość oceny indywidualnych sytuacji przez właściwe organy państwowe.

\subsection{Klauzula dobra dziecka}

Co do zasady w doktrynie klauzule generalne dzieli się na dwie kategorie. Pierwszy typ klauzul zawiera normę nakazującą organowi stosującemu prawo podjąć decyzję w zależności od przyjętej przez organ oceny, natomiast drugi typ nakazuje podjąć decyzję zgodnie z generalnymi zasadami postępowania o uzasadnieniu aksjologicznym. Według M. Zielińskiego i Z. Ziembińskiego, klauzula dobra dziecka należy do klauzul pierwszego typu, które odsyłają do zindywidualizowanych ocen związanych z konkretnym przypadkiem (Zieliński, Ziembiński 1988, 136-137). Autorzy podkreślają że standardy ocen wyznacza orzecznictwo wyższych instancji, chociaż przy klauzulach generalnych co do zasady trudno „przedstawić stanowczą argumentację za taką a nie inną oceną globalną w poszczególnych przypadkach granicznych" (tamże). W Polsce takie standardy zostały wyznaczone przede wszystkim przez Trybunał Konstytucyjny w powoływanym już wyroku K 18/02 czy przez Sąd Najwyższy w postanowieniu z dnia 5 lipca 2006 r. IV CSK 127/06.

\subsection{Klauzula dobra dziecka a ,interes społeczny”}

O klauzuli dobra dziecka mówi się jako o klauzuli generalnej mniejszego zasięgu, mieszczącej się w ramach innej klauzuli - zasad współżycia społecznego (Stojanowska 1999). Ponadto niekiedy dobro dziecka łączy się z interesem społecznym, tak jak w Kodeksie rodzinnym i opiekuńczym ${ }^{10}$. Ujęcie takie spowodowane było prawdopodobnie preferowaniem ogólnospołecznego kontekstu wartościowania w socjalistycznym ustawodawstwie. Kategoria interesu społecznego wskazywała na konieczność uogólniania ocen przy ustalaniu znaczenia dobra dziecka (Leszczyński 2000, 87).

\footnotetext{
${ }^{9}$ Podobnie Z. Radwański: „Klauzula generalna jest to zwrot niedookreślony zawarty w przepisie prawnym oznaczający pewne oceny funkcjonujące w jakiejś grupie społecznej, do których odsyła ów przepis przez nakaz uwzględniania ich przy ustalaniu stanu faktycznego podpadającego pod daną normę" (Radwański 2009, 44).

${ }^{10}$ Np. art. $61^{16}$, art. 86, art. $95 \S 3$, art. 154 KRO.
} 
W powojennej rzeczywistości standardem było pojmowanie dobra dziecka w zbieżności z interesem społecznym i rodzinnym. Wspomniany art. $20 \S 3$ Dekretu z 1946 r. wskazywał na wymóg sprawowania władzy rodzicielskiej zgodnie z dobrem dziecka i interesem społecznym. Uchwała SN z dnia 26 kwietnia 1952 r. CPrez 789/51 stanowiła jeszcze wyraźniej, że należy utożsamiać dobro dziecka z dobrem grupy społecznej. Również w uchwale SN z dnia 1976 r. III CZP 46/75 sąd uznał dobro dziecko za kryterium interesu społecznego.

W literaturze wciąż występują poglądy przemawiające za zbieżnością obu pojęć. W. Stojanowska spostrzega, że „odrębne traktowanie tych dwu kryteriów jest bezpodstawne i niedopuszczalne" (Stojanowska 1979, 20). M. Balcarek również stwierdził, że „dobro dziecka jest jednoznaczne z interesem społecznym” (Balcarek 1988, 25).

Kategoria interesu społecznego była zasadniczym elementem rozumienia wszystkich odesłań pozaprawnych socjalistycznego porządku prawnego (Leszczyński 2000, 87). Tymczasem zdaje się, że demokratyczne i liberalne społeczeństwa powinny traktować priorytetowo osobę ludzką (wraz z jej prawami, które są niezbywalne), a nie interes społeczny. Należy więc przychylić się do stanowiska wyrażonego już na początku przemiany ustrojowej przez Z. Radwańskiego, który podniósł, że za utożsamianiem obu pojęć kryje się niebezpieczeństwo interpretowania dobra dziecka przez pryzmat interesu społecznego, a „doświadczenia systemów totalitarnych wykazały, że jest to niebezpieczeństwo całkiem realne" (Radwański 1991). Pogląd ten podzielił SN w uchwale z 12 czerwca 1992 r. III CZP 48/92, przyjmując, że „trafnie zwraca się jednak ostatnio uwagę, że koncepcje zmierzające do zacierania różnicy między dobrem dziecka a interesem społecznym kryją w sobie niebezpieczeństwo takiego interpretowania pojęcia dobra dziecka, jak wymaga tego interes społeczny. Kierując się postanowieniami Konwencji, a zwłaszcza art. 3, należy jednak wyjść z założenia, że wartością pierwotną i nadrzędną jest dobro dziecka [...]. W demokratycznym państwie prawnym trzeba wyjść nie od priorytetu społeczeństwa, lecz od jednostki ludzkiej jako wartości nadrzędnej, i z tego punktu widzenia obdarzać dziecko szczególną troską". Trzeba ponownie podkreślić że również Konwencja o prawach dziecka wymaga, aby w wypadku sprzeczności pomiędzy dobrem dziecka a interesem społecznym pierwszeństwo miało dobro dziecka, ponieważ jest to „sprawa nadrzędna”. Zatem należy pozytywnie ocenić stopniowe odejście od łączenia tych pojęć w piśmiennictwie i judykaturze.

\subsection{Klauzula dobra dziecka a interesy innych osób}

Prawodawstwo i władze PRL utożsamiały dobro dziecka nie tylko z interesem społecznym, ale też z umacnianiem dobra rodziny, która miała na celu kształtowanie osobowości dziecka w zgodzie z oficjalnie wyznawanymi wartościami i moralnością socjalistyczną. 
Obecnie dominuje stanowisko, że w przypadku kolizji interesów dziecka i innych osób - zwłaszcza rodziców - dobro dziecka winno mieć zawsze znaczenie priorytetowe (Stojanowska 1999). Zazwyczaj najlepszy interes dziecka i rodzica są ze sobą zbieżne, jednakże gdy nie da się ich pogodzić, przewagę powinno mieć dobro dziecka.

Oczywiście, wzgląd na dobro dziecka nie oznacza całkowitego pominięcia godnego ochrony interesu jego rodziców, co znalazło potwierdzenie m.in. w wyroku SN z dnia 17 grudnia 1965 r. I CR 309/65. Sąd stwierdził w nim, że „dobro małoletniego dziecka nie eliminuje całkowicie interesu rodziców jako jednej z przesłanek rozstrzygania spraw z zakresu stosunków między rodzicami a dziećmi. Jeżeli ochrona dobra dziecka da się pogodzić z interesem rodziców, to sąd nie może interesu rodziców nie wziąć pod uwagę nawet przy założeniu, że rozstrzygnięcie wywoła pewne przejściowe skutki ujemne dla dziecka". Natomiast w wyroku SN z dnia 6 września 1968 r. I CR 249/68 sąd wyraził pogląd, że instytucja przysposobienia nie jest ukierunkowana na dobro przysposabiających, lecz na interes małoletniego dziecka. Ponadto w uchwale SN z dnia 9 czerwca 1976 r. III CZP 46/75 sąd przyjął, że zasada dobra dziecka jest nie tylko kierowana do instytucji państwowych i sądów, ale przede wszystkim rozstrzyga o tym, jak rodzice powinni wykonywać swe obowiązki względem dzieci oraz po raz wtóry potwierdza supremację dobra dziecka nad interesami rodziców.

\subsection{Klauzula dobra dziecka a uwarunkowania kulturowe}

Dobro dziecka powinno być postrzegane nie tylko w kontekście innych dóbr $\mathrm{i}$ interesów, ale też w świetle tradycji narodowych, co potwierdza m.in. preambuła Konwencji. Jednak, jak zostało już wielokrotnie podkreślone, w pierwszym rzędzie należy kierować się dobrem dziecka, co nie może być uchylone ani zawieszone nawet w sytuacjach nadzwyczajnych.

Niemniej, jak trafnie spostrzega A. Łopatka, uwarunkowania kulturowe w pojmowaniu dobra dziecka nie mogą być lekceważone, jednakże nie powinny nigdy mieć pierwszeństwa przed zasadą dobra dziecka wyrażoną w Konwencji o prawach dziecka i w polskich ustawach. Pojmowanie dobra dziecka powinno być pozbawione także kulturowego relatywizmu, zwłaszcza gdy dotyczy to ,poddawania się tradycyjnym praktykom szkodliwym dla dziecka” (Łopatka 2000, 10). Można w tym miejscu ponownie przywołać deklaracje Polski do Konwencji o prawach dziecka, które pozwalają na interpretację jej przepisów zgodnie z tym, co nakazuje „ochrona tradycyjnych wartości, moralności i polskiej kultury”. Warto zastanowić się, w świetle argumentów A. Łopatki, czy taka deklaracja może w istocie stać w sprzeczności z dobrem dziecka, zwłaszcza w świetle wyżej omówionych uwag Komitetu Praw Dziecka. 


\section{PODSUMOWANIE}

Pojęcie interesu dziecka stanowi interpretacyjne wyzwanie, co miał na celu wykazać niniejszy artykuł. Z jednej strony, zamknięcie tego pojęcia w ramy definicji byłoby niepożądane, ponieważ celem klauzul generalnych jest przyznanie niezbędnej swobody decyzyjnej umożliwiającej stosowną wykładnie prawa, z drugiej jednak - rodzi niebezpieczeństwo nadużyć.

Naturalnym odruchem w każdym społeczeństwie jest troska o dobro najsłabszych jednostek, szczególnie dzieci. Idea ta znajduje odzwierciedlenie w dokumentach o zasięgu międzynarodowym, takich jak Konwencja o prawach dziecka, ale też w polskich przepisach, które od dawna posługują się pojęciem dobra dziecka. Pomimo to nieustannie pojawiają się problemy interpretacyjne dotyczące zakresu i znaczenia klauzuli dobra dziecka. W artykule starano się wykazać, że pomimo wyraźnego odejścia od łączenia dobra dziecka z interesem społecznym, niekiedy nadal interes dziecka stawia się niżej. Wskazują na to między innymi deklaracje złożone przez Polskę, które chociaż są wyłącznie postulatem, wskazują kierunek interpretacyjny dla instytucji państwowych. Tendencja ta nie zawsze jest zgodna z najlepiej rozumianym interesem dziecka, na co wskazuje Komitet Praw Dziecka, zalecając wycofanie się z tych deklaracji.

W pracy starano się też wykazać, że często w Polsce nie podkreśla się nadrzędnej roli dobra dziecka w kontekście władzy rodzicielskiej. Zazwyczaj interesy dziecka i rodzica są zbieżne, jednak nie powinno to oznaczać automatycznego utożsamiania ich ze sobą. Dodatkowo należy podkreślić, że wartości kulturowe i normy obyczajowe, chociaż istotne, nie powinny być traktowane jako priorytet w sytuacji, gdy sprawa dotyczy dobra dziecka. Ma to szczególne znaczenie w kontekście konserwatywnych norm społecznych, które, pomimo liberalizacji, wciąż są dominujące w przypadku Polski.

Niewatpliwie kwestia klauzuli dobra dziecka, pomimo poprawy sytuacji praw dziecka w ogóle, jest nadal problemem istotnym i wymagającym nieustannej analizy. W obliczu zmieniającej się rzeczywistości politycznej i prawnej w Polsce i w Europie, należy stale przywoływać postulat dobra dziecka, aby nigdy nie stał się drugoplanowym. Warto przywołać tradycyjna, wywodzącą się od Platona i Arystotelesa definicję „dobro jest celem wszelkiego dążenia”. Nie pozostaje zatem nic innego niż nieustannie zmierzać ku tej idei, szczególnie jeśli dotyczy dzieci.

\section{BIBLIOGRAFIA}

Balcarek, Marian. 1988. Prawa dziecka. Warszawa: Wydawnictwa Szkolne i Pedagogiczne. Balcerzak, Michał. Sebastian Sykuna. 2010. Leksykon ochrony praw człowieka. 100 podstawowych pojęć. Warszawa: C.H. Beck.

Leszczyński, Leszek. 1986. Klauzule generalne w stosowaniu prawa. Lublin: Wydawnictwo UMCS. Leszczyński, Leszek. 2000. Stosowanie generalnych klauzul odsyłajacych. Kraków: Zakamycze. 
Łopatka, Adam. 1991. Konwencja o prawach dziecka a prawo polskie. Warszawa: ZPiM KS. Łopatka, Adam. 2000. Dziecko. Jego prawa człowieka. Warszawa: PWN Iuris.

Kołodziejski, Stanisław. 1965. „Dobro wspólnych nieletnich dzieci - jako przesłanka orzeczenia rozwodu". Palestra 9.

Kuźniar, Roman. 1992. O prawach człowieka. Idee, instytucje, praktyka. Warszawa: PWN.

Nowacki, Józef. 2003. Studia z teorii prawa. Kraków: Zakamycze.

Piszko, Robert. 2001. „Odesłania, klauzule generalne, luzy decyzyjne”. Ruch Prawniczy, Ekonomiczny $i$ Socjologiczny 1-2.

Radwański, Zbigniew. 2009. Prawo cywilne - czesść ogólna. Warszawa: C.H. Beck.

Smyczyński, Tadeusz. 1994. Konwencja o prawach dziecka. Wybrane zagadnienia prawne i socjalne. Warszawa: Polski Komitet UNICEF.

Smyczyński, Tadeusz. 1999. Konwencja o prawach dziecka. Analiza i wykładnia. Poznań: PW Ars boni et aequi.

Smyczyński, Tadeusz. 2012. Prawo rodzinne i opiekuńcze. Warszawa: C.H. Beck.

Wróblewski, Jerzy. 1964. „Przepisy odsyłające”. Zeszyty Naukowe Uniwersytetu Eódzkiego 1.

Zieliński, Maciej, Zygmunt Ziembiński. 1988. Uzasadnianie twierdzeń, ocen i norm w prawoznawstwie. Warszawa: PWN.

\section{Karolina Mendecka}

\section{THE PRINCIPLE OF THE BEST INTEREST OF THE CHILD IN THE CONVENTION ON THE RIGHTS OF THE CHILD AND IN THE POLISH LAW (SELECTED PROBLEMS)}

\footnotetext{
Abstract. Children's rights are one of the most important and challenging international and national regulations. The Convention on the Rights of the Child as well as the Polish law explicitly stipulate that the best interest of the child has to be taken as primary consideration. The scope of this principle is defined mainly by the judicatory and the doctrine. The best interest of the child principle is not only primary, but should be superior to other interests and principles. Where a conflict of interests arises, the child's best interest should always be a priority. This article elaborates on the condition of children's rights in Poland, with particular reference to the best interest of the child principle in the light of the Convention on the Rights of the Child and of the Polish legal system.

Keywords: child, children's rights, the child's best interest, the principle of the child's best interest, the Convention on the Rights of the Child.
} 